\title{
ФОРМУВАННЯ ПРОФЕСІЙНОЇ КОМПЕТЕНТНОСТІ СУЧАСНИХ ФАХІВЦІВ У ПРОЦЕСІ ПРОВЕДЕННЯ ВІДЕОКОНФЕРЕНЦІЙ
}

Данилюк С. С. Формування професійної компетентності сучасних фахівців у процесі проведення відеоконференцій.

Статтю присвячено висвітленню формування професійної компетентності сучасних фахівців в аспекті використання в навчальному процесі відеоконференцій як сучасної інтернет-технології. Крім того, визначено переваги використання відеоконференцій в навчальному процесі. Також увагу зосереджено на основних напрямках попередньої роботи з підготовки відеоконференцій.

Ключові слова: інтернет-технологія, відеоконференція, професійна компетентність, сучасні фахівці.

Данилюк С. С. Формирование профессиональной компетентности современных специалистов в процессе проведения видеоконференций.

Статья посвящена освещению формирования профессиональной компетентности современных специалистов в аспекте использования в учебном процессе видеоконференций как современной интернет-технологии. Кроме того, определены преимущества использования видеоконференций в учебном процессе. Также внимание уделяется основным направлениям предварительной работы по подготовке видеоконференций.

Ключевые слова: интернет-технология, видеоконференция, профессиональная компетентность, современные специалисты.

Danylyuk S.S. Formation of Modern Specialists' Professional Competence in the Process of Conducting of Videoconferences.

The paper deals with the highlighting of the formation of modern specialists' professional competence in the aspect of the usage of such Internet technology as videoconference in the educational process. Furthermore, the benefits of using videoconferencing in the educational process are defined. Attention is also focused on basic directions of the preparatory work aimed at conducting videoconferences.

Key words: Internet technology, videoconference, professional competence, modern specialists.

На сучасному етапі розвитку суспільства спостерігається суттєвий вплив на нього інформаційно-комунікаційних технологій (ІКТ), які використовуються в усіх сферах людської діяльності. Вони сприяють забезпеченню поширення інформаційних потоків у суспільстві, що має своїм наслідком утворення глобального інформаційного простору. Комп’ютеризація навчання $€$ невід'ємною та важливою частиною цих процесів.

Діапазон використання комп'ютера в навчальному процесі $є$ достатню широким і охоплює ті сфери, які пов'язані безпосередньо з навчанням. Він варіюються від тестування студентів, обліку їхньої успішності, ведення характеристик аж до гри. У навчальному процесі комп'ютер може бути як об'єктом вивчення, так і засобом навчання, тобто можливі два напрями комп'ютеризації навчання. У першому випадку 
засвоєння знань, навичок і вмінь сприяє усвідомленню можливостей комп'ютера, а також його використання при розв'язанні різноманітних завдань, іншими словами, приводить до опанування комп'ютерною грамотністю. У другому випадку комп'ютер $\epsilon$ потужним засобом підвищення ефективності навчання. Означені два напрями й утворюють основу комп'ютеризації навчання як соціального процесу [4, с. 9].

Безперечну цінність для визначення сутності та змісту ІКТ-компетентності становлять роботи В. Адольфа, О. Зайцевої, І. Ісаєва й ін. Аналіз теоретичних досліджень і практичного досвіду сучасної педагогічної діяльності показує, що, незважаючи на пильну увагу до підвищення якості професійної підготовки студентів, проблема використання IКТ як засобу формування професійної компетентності фахівців залишається недостатньо вивченою.

Сутність процесу інформатизації, який набув значного поширення в царині освіти і значною мірою впливає на динаміку розвитку сучасного суспільства, розкрито у процях наукоців (Д. Белл, А. Вербицький, Т. Вороніна, К. Колін, А. Тоффлер та ін.).

Mema cmammi - дослідити, як відбувається в навчальному процесі формування професійної компетентності сучасних фахівців за допомогою використання такої інтернет-технології, як відеоконференція.

Відеоконференція (відеоконференцзв'язок) $\quad$ с сучасною комунікаційною технологією, що має синхронний характер і дозволяє спілкуватися, обмінюватися інформацією на відстані в режимі реального часу, використовуючи можливості звичайних персональних комп'ютерів і різних видів відеокамер [2, с. 42]. У цьому випадку зазвичай використовується спілкування типу «один на один» (консультація), «один до багатьох» (лекція, прес-конференція) або «багато до багатьох» (телеміст) [7, с. 44].

Відеоконференції дозволяють передавати всім учасникам звук і зображення, а також різні електронні документи, що містять текст, таблиці, графіки, комп'ютерну анімацію, відеоматеріали в режимі реального часу. Звичайно, відеоконференції не можуть повністю замінити особистого спілкування, але вони дозволяють домогтися принципово нового рівня спілкування суб'єктів навчального процесу, часом розділених тисячами кілометрів [5, с. 114]. Перевага відеоконференції полягає в можливості передавання рухливого зображення [3, с. 24].

Можливості сучасних відеоконференцій є великими, а якість настільки наближеною до реального живого спілкування, що нині практично не залишилося напрямів, у яких ця технологія не використовується. Так, у царині професійної освіти сучасних фахівців за допомогою відеоконференції студенти можуть спілкуватися й консультуватися 3 іншими студентами, викладачами або фахівцями, котрі перебувають в інших містах і країнах, брати участь у роботі круглих столів [7, с. 44]. Так само, як і при очному навчанні, студенти бачать дії викладача, а викладач- реакцію студентів. Використання можливостей комп'ютерної візуалізації навчальних матеріалів i їхня оптимальна структуризація в електронному вигляді, безсумнівно, підвищують якість сприйняття інформації [5, с. 114].

Викладач має надати допомогу студентам у їхній підготовці до відеоконференцій. Під час занять вони можуть виступати перед аудиторією (групою) 3 підготовленими й непідготовленими промовами. Можна використовувати відеокамеру для подальшого аналізу, а також організовувати симуляції відеоконференцій. Будь-який курс презентацій та/ або ораторської майстерності також готує сучасних фахівців до участі у відеоконференціях. 
Викладачеві слід допомогти студентам навчитися говорити чітко, тримаючи мікрофон на певній відстані від особи. Часто допомагає досягненню цієї мети порівняно повільний темп мовлення. Можна запропонувати студентам кліше, які використовують у веденні теледіалогів. Майбутні фахівці, беручи участь у відеоконференції, мають представлятися, коли їм надають слово. Як частину навчання ефективної комунікації, студентів слід навчати тому, як правильно ставити питання.

Нині виокремлюють такі позитивні аспекти використання відеоконференцзв'язку в навчальному процесі: а) під час відеоконференції студентилінгвісти спеціально отримують можливість у реальних умовах (малознайома реальна аудиторія, незвичайний формат), але у віртуальному середовищі практикувати навички проведення презентацій і комунікативні навички; б) оскільки проведення відеоконференції у студійному форматі вимагає ретельної і всебічної підготовки, майбутні фахівці вдосконалюють різні навички до іiі проведення; в) у студентів формується навичка комунікації у специфічному середовищі, (хоч учасники конференції знаходяться дуже близько одне від одного, віртуальний бар'єр, відеокамера, нерутинна атмосфера серед учасників визначають взаємодію комуні кантів [9].

Визначимо основні напрямки попередньої роботи 3 підготовки відеоконференції. По-перше, учасники й організатори мають досконально вивчити особливості роботи використовуваної системи. Для фасилітатора, який проводить конференцію, важливо, у використанні студійної системи залучити кілька добровольців із числа сучасних фахівців для розроблення й підтримання в разі необхідності альтернативних сценаріїв відеоконференцсеанса. Зазвичай, фасилітатор не торкається технічних проблем встановлення й підтримання зв'язку, але не зайвим буде обговорити з технічним персоналом варіанти конференції за умови виникнення технічних ускладнень.

По-друге, в обговоренні тематики та сценарію відеоконференції 3 іншою стороною (фасилітаторами 3 іншого навчального закладу) слід передбачити зміст i напрямки дискусії в кожній студії, якщо відбудуться накладки зі зв'язком або проходженням відео- чи аудіосигналу тощо. Не зайвим буде пробне попереднє встановлення зв'язку за деякий час до проведення відеоконференції.

По-третє, у проведенні конференції в настільному режимі складно вписати таку сесію у формат денного навчання в години аудиторних занять. Викладачеві слід якимось чином охопити участю в таких сесіях усіх студентів. Як один із варіантів, можна проводити паралельно кілька конференцій за участю 3 кожного боку від двох до шести осіб (за одним комп'ютером). Іншим варіантом може бути черговість участі студентів у цих заходах. Учасники можуть готувати й подавати в аудиторії для всієї групи (якщо група перевищує десять осіб) своєрідний звіт про проведення відеомосту зі студентами 3 іншого університету. За великих технічних можливостей і належної матеріальної бази, уможливлюється паралельне проведення кількох сеансів, а потім аналіз і зіставлення результатів [8, с. 66-67].

Нині відеоконференції $є$ одним з ефективних засобів дистанційного навчання та спілкування, які максимально за своїми параметрами близькі до реального навчання в режимі віртуальної взаємодії. Вони використовуються в багатьох ВНЗ як у процесі навчання, підвищення кваліфікації, так i в реальній практиці наукового та професійного спілкування. Наприклад, у межах віртуального навчання відеоконференція дозволяє проводити лекційні та практичні заняття між головним ВН3 і його філіями, розташованими в різних містах чи країнах в багатоточковому режимі $[6$, с. 88$]$. 
Відомо, що більшу частину інформації людина отримує візуально. Саме тому дуже важливо, щоб студенти не тільки могли чути викладача i бачити його презентацію або конспект, а й мати зоровий контакт із ним особисто. Це є дуже важливим психологічним аспектом, який підвищує ефективність навчального процесу.

Саме тому візуальний контакт із віртуальною аудиторією необхідно підтримувати для створення приємної атмосфери й умов для вільного спілкування. Для цього слід розглядати відеокамеру як учасника спілкування й постійно підтримувати 3 відеокамерою зоровий контакт, а також виявляти рівний інтерес до учасників не лише у студії / кімнаті, а й у віртуальній аудиторії. Потрібно подолати скутість, яка виникає у багатьох людей перед відеокамерою, особливо якщо не звертатися безпосередньо до них, допомагаючи встановлювати й підтримувати контакт. Віртуальному спілкуванню часто притаманні складності сприйняття питань, оскільки негативну роль можуть зіграти технічні аудіоперешкоди та психологічний бар'єр. Ведучому слід повторювати питання свої і з власного залу, якщо з віртуальної аудиторії відразу після питання (п’ять-сім секунд) не отримано відповідь. Фасилітатор у віртуальній аудиторії може заохочувати свою аудиторію, наприклад, переформулювавши питання, адресуючи його будь-кому, хто потенційно може або хоче відповісти на це запитання. Організаторам відеоконференцій необхідно обирати актуальні, цікаві для сучасних фахівців питання i теми для сесій, продумувати оригінальні форми подання інформації, щоб підтримувати інтерес учасників для продовження конференції [8, с. 68].

Завдяки відеоконференціям сучасні фахівці з різних міст і країн можуть бути присутні у віртуальній аудиторії: бачити й чути викладача, ставити йому запитання, дискутувати між собою, захищати свою роботу перед іншими студентами. Іншими словами, відеоконференція надає всі ті самі можливості студентам і викладачам, що й реальна аудиторія з присутніми там людьми [1].

Вдалому проведенню відеоконференції може також сприяти використання аудіовізуальних технічних засобів. Проте вони також уможливлюють створення технічних проблем для чіткого передавання зображень і звуку. Слід звернути увагу на такі аспекти: 1) технічні параметри телевізійного екрану мають приймати зображення без спотворень; 2) за використання титрів чи будь-яких текстових повідомлень перевагу слід віддавати великому простому кеглеві, який учасники відеоконференції у віртуальній аудиторії зможуть прочитати, не наближаючись до екрану; 3) для титрів не слід використовувати яскраві кольори на контрастному тлі. Перевагу необхідно надавати кольорам із середини спектра. За використання чорного шрифту для тла переважно обирати пастельні кольори; 4) використовуючи текстовий і графічний матеріали, потрібно розрахувати час їхньої демонстрації так, щоб усі мали час прочитати й роздивитися ілюстраційний матеріал; 5) якщо планується показати відеоматеріали під час відеоконференції, то не слід використовувати великі відеофрагменти, оскільки зображення передається з помітними перешкодами. У випадку, коли відеоматеріали $\epsilon$ дуже важливими для відеоконференції, краще переслати їхню копію заздалегідь, аби інша сторона могла переглянути іiї під час конференції безпосередньо у студії; 6) якщо відеоконференція проводиться за участю закордонного університету, необхідно приділити увагу питанням авторського права на використовувані під час конференції відеоматеріали, оскільки в багатьох країнах потрібен дозвіл автора на трансляцію його матеріалів. Це дозволить уникнути можливих проблем [8, с. 68-69]. 
У межах відеоконференції читання лекцій здійснюється за допомогою презентацій на основі модульного навчання. Заздалегідь підготовлені презентації 3 курсу використовують графіку, картинки, фотографії, анімацію, невеликий за обсягом текст. У відеоконференції викладач може використовувати тестові завдання для перевірки знань студентів із пройденого матеріалу курсу [6, с. 88-89].

Відеоконференції надають для галузі освіти такі можливості [1]: а) проводити дистанційні лекції із провідними викладачами світу, зокрема із зарубіжних університетів. Навчальні заклади можуть охопити більшу аудиторію слухачів та заощадити час i кошти на відрядження викладачів; б) забезпечити віддалену присутність на заняттях. Люди з обмеженими можливостями можуть отримати освіту, не виходячи 3 дому, а відсутні 3 різних причин студенти мають змогу відвідати заняття або переглянути його в запису; в) здійснювати оперативний обмін навчальним матеріалом. Натисканням двох кнопок викладач отримує можливість роздати всім студентам необхідні для навчання матеріали; г) проводити широкомасштабні наукові дискусії та семінари. На практиці організація дискусій і семінарів є доволі клопіткою справою: потрібно знайти приміщення, зібрати всіх учасників, витратити багато часу та сил на організаційні питання. Відеоконференції дозволяють звести до мінімуму зусилля 3 організації заходу й уможливлюють фінансові заощадження на оренді приміщення та відрядних витратах учасників; д) організувати повторний перегляд навчальних матеріалів і лекцій з архіву. Студенти, які пропустили заняття 3 різних причин можуть легко надолужити згаяне; е) забезпечити проведення дистанційних тренінгів і таким чином швидко i ефективно підвищувати рівень кваліфікації персоналу.

Відеоконференції можуть бути організовані та проведені в навчальний (дистанційне заняття) чи позанавчальний час. Тематика конференцій обирається й узгоджується заздалегідь. Нерідко в ході конференції сучасним фахівцям доводиться спілкуватися іноземною мовою 3 носіями мови, ставити їм запитання. Відеоконференції $є$ тією технологією, яка $є$ сумісною 3 багатьма організаційними формами й методами навчання. Вона може бути реалізована на різного роду заняттях, у проведенні різноманітних комунікаційних проектів. Наприклад, під час проведення лабораторних занять у режимі відеоконференцій, коли викладач i студенти зустрічаються на екранах [7, с. 44].

Важливо, щоб відеоконференції не перетворилися на засіб, який надає інформацію сучасним фахівцям у готовому вигляді, або на заняття, де записується навчальний матеріал під диктовку. Викладачеві слід ретельно продумувати зміст і сценарій відеоконференцій, їхню періодичність, чітко визначати, яку роботу має бути проведено студентами в інтервалі між конференціями. Першим заняттям із виучуваної дисципліни в режимі відеоконференції може бути ввідне (настановче заняття)презентація заняття або всього матеріалу курсу [5, с. 114].

Дистанційні лабораторні роботи виконуються в тих випадках, коли потрібно проводити навчальні дослідження, експерименти, заміри на дорогому обладнанні, яке $є$ в іншому ВНЗ. Викладачеві необхідно ретельно планувати та готувати кожен навчальний захід із використанням цього засобу спілкування, налаштовувати учасників відеоконференцій на новий для них режим роботи, заздалегідь вивчити питання технічної сумісності навчальних програм й уточнити час і розклад роботи всіх учасників проекту, обладнати класи спеціальною технікою, зокрема засобами презентування аудіовізуальної інформації [7, с. 44].

Проведення відеоконференцій у процесі навчання вимагає спеціальних знань у 
царині електронної педагогіки. Оскільки відеоконференція передбачає інтерактивне спілкування викладача зі студентами, то електронна педагогіка висуває особливі вимоги до психолого-педагогічної підготовки й організації самого навчального процесу як із боку викладача, так і студентів. Тому в академічній групі обов'язково має знаходитися співробітник (тьютор), який допомагає організовувати процес навчання в аудиторії. Для організації навчального процесу у вигляді відеоконференції викладач має бути підготовленим не лише методологічно, а й технічно, що вимагає знань і умінь працювати 3 комп'ютером, 3 іншими керувальними системами для перемикання режиму моніторів, різних програм. У деяких ВНЗ для цього є технічні працівники, які допомагають викладачеві у проведенні відеоконференцій. Однак дуже важливо, щоб викладач мав інформаційно-комунікаційні навички керування цим навчальним процесом [6, с. 89].

Участь студентів і викладачів у відеоконференціях розвиває навчальні й міжкультурні комунікації як на рівні «студент-викладач», так і між окремими студентами, викладачами, колективами навчальних закладів. Інформаційна навчальна взаємодія здійснюється вже на глобальному рівні, у ВНЗ з'являється можливість виходу у світове співтовариство, спілкування 3 людьми 3 інших міст і країн. Нині формуються різного роду інтелектуальні об'єднання, організовані за особистісними інтересами користувачів. Наступним кроком у розширенні використання можливостей Інтернету в царині освіти стає формування так званих онлайн-спільнот, розподілених колективів, які спільно працюють над створенням різних документів, цифрових інформаційних або освітніх ресурсів тощо [7, с. 44].

Відеоконференції як комунікаційна технологія нині використовуються переважно у ВНЗ, які мають розгалужену мережу філій. Основною перешкодою для широкого використання зазначеної інтернет-технології $\epsilon$ велика вартість обладнання, котре не завжди $є$ доступним у локальних навчальних центрах (філіях) головного BH3 [2, c. 42].

На жаль, наразі відеоконференції не використовуються повсюдно, оскільки, як і раніше, наявні технічні бар'єри для їхнього проведення, котрі полягають у пропускній спроможності каналів зв'язку і технічних обмеженнях аналогових телефонних ліній, а також у швидкості кодування переданої і декодування отриманої інформації, яка впливає на якість отримуваних відео- й аудіосигналів.

Багато років була поширена думка про те, що відеоконференції $є$ дорогою інтернет-технологією. Проте телекомунікаційні технології, як і всі сучасні технології, iз моменту їхнього розроблення починають стрімко дешевшати. Нині відеоконференцзв'язок є доступним і доволі вдосконаленим, аби забезпечити його високу якість. Ці чинники роблять відеоконференції широко використовуваною інтернет-технологією в царині освіти. Найбільший інтерес становить зазначена інтернет-технологія для програм дистанційної освіти. Проте не виключається інтеграція відеоконференцій у систему денної освіти. Наприклад, відомі науковці та практики можуть виступати з лекціями «на відстані».

У підготовці занять у режимі відеоконференції викладачеві слід звернути увагу на низку аспектів. Він має визначити: якою є мета заняття і що повинні набути студенти в його ході; в якій формі проходитиме відеоконференція (лекція, семінар, дискусія тощо); які аудіо- та відеоматеріали, роздаткові й ілюстративні матеріали передбачається використовувати; якою буде тривалість відеоконференції; чи $\epsilon$ необхідним додаткове обладнання для демонстрації відеоматеріалів або титрів до інструкцій; чи потрібно передавати будь-які матеріали віртуальним учасникам 
відеоконференції завчасно тощо.

За постійного проведення відеомостів із іншими університетами, слід унести елементи довгострокового планування 3 тим, щоб викладачі могли узгоджувати графік проведення конференцій із колегами 3 інших університетів і зв'язати їхню тематику 3 навчальними планами та програмами навчання. За контактів із зарубіжними університетами й навчальними закладами необхідно брати до уваги різницю в часі та графіки проведення занять, щоб визначити час, зручний для обох (чи всіх) сторін.

Далі слід розв'язати технічні питання, головним із яких є вибір системи та програмного забезпечення. Якщо планується проведення відеоконференцій на регулярній основі, важливим буде визначити їхню тематику. Крім згаданих навчальних планів і програм навчання, необхідно виокремити ті теми, які становлять інтерес для всіх учасників. Не зайвим буде провести опитування колег і студентів. Відеоконференції частіше доповнюють заняття 3 певної теми, а не замінюють їх повністю [8, с. 70-71].

Отже, використання відеоконференцій уможливлює й робить порівняно дешевим проведення консультацій і обговорення актуальних проблем навчання та самостійної роботи з викладачами й експертами, а також із однокурсниками в режимі реального часу. Технологія може бути корисною не лише в системі дистанційної освіти, а й як доповнення до денної системи освіти.

Перспективними відеоконференції $є$ й для самоосвіти. Головною організаційною проблемою тут може стати створення контактної аудиторії, із якої сучасні фахівці можуть виходити на зв'язок для обговорення тих проблем, які виникають при самостійному опануванні тем і дисциплін.

Для ефективного проведення й участі у відеоконференції - як викладача, модератора (ведучого) чи студента - слід розвивати нові соціально-психологічні, інформаційно-комунікаційні та науково-аналітичні компетенції. Такі компетенції можуть бути сформовані лише в результаті спеціального навчання та практичної діяльності, тобто безпосередньої участі у відеоконференціях, що вимагає від викладача додаткових зусиль в організації та проведенні таких конференцій.

Виявлення й опис переваг і недоліків використання інформаційно-комп'ютерних технологій у навчальному процесі має перспективу дослідженні особливостей використання інших інтернет-технологій, зокрема, блогів, підкастів, електронної пошти, форумів, чатів тощо у формуванні професійної компетентності сучасних фахівців.

\section{Література}

1. Видеоконференции в образовании [Электронный ресурс] // REALEM CONFERENCE Software : [Сайт]. - Режим доступа: http://realemconference.com/video conferencing-for-education. 2. Захарова И. Г. Информационные технологии в образовании / И. Г. Захарова. - М. : Издательский центр «Академия», 2003. - 192 с. 3. Интернет-технологии в образовании / Р. Н. Абалуев [и др.]. - Тамбов : ТГТУ, 2002. - Ч. 3. - 114 с. 4. Колин К. К. Информационное общество / К. К. Колин. Челябинск : ЧГАКИ, 2010. - 27 с. 5. Красильникова В. А. Информационные и коммуникационные технологии в образовании / В. А. Красильникова. - Оренбург : ГОУ ОГУ, 2006. - 235 с. 6. Лупанов В. Н. Интерактивные видеоконференции в системе открытого образования: опыт, проблемы и перспективы / В. Н. Лупанов // Информационные технологии в образовании: сб. трудов участников XII Междунар. конф. - М. : МИФИ, 2008. - С. 87-89. 7. Панюкова С. В. Использование 
информационных и коммуникационных технологий в образовании / С. В. Панюкова. М. : Издательский центр «Академия», 2010. - 224 с. 8. Раицкая Л. К. Интернетресурсы в преподавании английского языка в высшей школе: классификация, критерии оценки, методика использования : [монография] / Л.К. Раицкая. - М. : МГИМОУниверситет, 2007. - 199 с. 9. Desk Videoconferencing: Novelty or Legitimate Teaching Tool? [Electronic Resource] // EducationWorld: [Site]. - Access mode: http://www.educationworld. com/a_curr/curr120.shtml

УДК $159.9: 371.134$

Світлана Карсканова

\section{ВІД ПРОФЕСІЙНОГО САМОВИЗНАЧЕННЯ ДО ПРОФЕСІЙНОГО РОЗВИТКУ МАЙБУТНЬОГО ВЧИТЕЛЯ}

Карсканова С. В. Від професійного самовизначення до професійного розвитку майбутнього вчителя.

У статті розглянуто професійне самовизначення молоді та подальший розвиток вчителя. Проаналізовано складники професійного зростання фахівця освіти. Обгрунтовано пріоритет активних методів навчання для розвитку фахівця освіти та психологічний тренінг як засіб забезпечення його професійного розвитку.

Ключові слова: професійне самовизначення молоді, професійні мотиви, професійний розвиток, психологічний тренінг.

Карсканова С. В. От профессионального самоопределения к профессиональному развитию будущего учителя.

В статье рассматривается профессиональное самоопределение молодежи и дальнейшее развитие учителя. Анализируются составляющие профессионального роста. Обосновывается приоритет активных методов обучения для развития специалиста образования и психологический тренинг как средство обеспечение его профессионального развития.

Ключевые слова: профессиональное самоопределение молодежи, профессиональные мотивы, профессиональное развитие, психологический тренинг.

Karskanova S. V. From professional self-determination to professional development of future teacher

The paper considers the self-determination of young professional and further development of the teacher. Analyzes the components of professional development and professional education. Substantiates the priority of active learning for the development of professional education and psychological training as providing.

Key words: professional development of young, professional motivation, psychological training.

Модернізація освіти в Україні зумовила багато питань, розв'язання яких неможливе без основних учасників цього процесу - фахівців освіти. Кожна країна зацікавлена в тому, щоб підготувати когорту таких учителів, які б не лише забезпечували кількісну реалізацію завдань обов'язкового навчання, але й підносили на значно вищий рівень освіченість і культуру іiі громадян. Здійснити професійну підготовку такого фахівця надзвичайно складно. На перешкоді стають об'єктивні і суб'єктивні чинники, породжені суспільними перетвореннями, технічними здобутками, стереотипами і формалізмом сучасної системи 